\title{
Analisis Faktor-Faktor yang Mempengaruhi Nilai Tukar Rupiah Periode 1999Q1-2019Q2
}

\author{
Analysis of Factors Affecting the Rupiah Exchange Rate \\ for the 1999Q1-2019Q2 Period
}

\author{
Erric Wijaya \\ Program Studi Manajemen, STIE Indonesia Banking School, Jakarta \\ e-mail korespondensi: erric.wijaya@ibs.ac.id
}

\begin{tabular}{|c|c|}
\hline Info A & Abstrak \\
\hline $\begin{array}{l}\text { Riwayat Artikel: } \\
\text { Diterima: } 07 \text { Februari } 2020 \\
\text { Disetujui: } 24 \text { Februari } 2020 \\
\text { Dipublikasikan: Juli } 2020\end{array}$ & $\begin{array}{l}\text { Nilai tukar memegang peranan penting dalam mempengaruhi tinggi rendahnya } \\
\text { perdagangan internasional Indonesia terhadap negara mitra dagang. Penelitian ini } \\
\text { membahas mengenai faktor-faktor yang mempengaruhi nilai tukar rupiah }\end{array}$ \\
\hline $\begin{array}{l}\text { Nomor DOI } \\
\text { 10.33059/jseb.v11i2.1919 } \\
\text { Cara Mensitasi : } \\
\text { Wijaya, E. 2020. Analisis } \\
\text { Faktor-Faktor yang } \\
\text { Mempengaruhi Nilai Tukar } \\
\text { Rupiah Periode 1999Q1- } \\
\text { 2019Q2. Jurnal Samudra } \\
\text { Ekonomi dan Bisnis. 11(2): } \\
\text { 197-209. }\end{array}$ & $\begin{array}{l}\text { variabel-variabel yang diduga mempengaruhi perubahan nilai tukar tersebut } \\
\text { adalah tingkat inflasi, tingkat bunga (SBI), harga minyak dunia, nilai ekspor, dan } \\
\text { nilai impor. Penelitian ini selama tahun } 1999 \text { kuartal } 1 \text { sampai } 2019 \text { kuartal } 2 . \\
\text { Hasil penelitian menunjukkan terdapat hubungan jangka panjang maupun jangka } \\
\text { pendek tingkat inflasi, tingkat bunga, harga minyak dunia, ekspor, dan impor } \\
\text { terhadap nilai tukar. Pada jangka pendek, tingkat bunga dan harga minyak dunia } \\
\text { berpengaruh signifikan terhadap nilai tukar. Pada jangka panjang, tingkat inflasi, } \\
\text { harga minyak dunia, dan nilai impor berpengaruh signifikan terhadap nilai tukar. } \\
\text { Kata Kunci: Nilai Tukar, Inflasi, Tingkat Bunga, Harga Minyak Dunia, Ekspor, } \\
\text { Impor. }\end{array}$ \\
\hline
\end{tabular}

\begin{tabular}{|c|c|}
\hline Article Info & Abstract \\
\hline $\begin{array}{l}\text { Article History: } \\
\text { Received: } 07 \text { February } 2020 \\
\text { Accepted: } 24 \text { February } 2020 \\
\text { Published: July } 2020\end{array}$ & $\begin{array}{l}\text { The exchange rate play an important role in influencing the level of Indonesia's } \\
\text { international trade towards trading partner countries. This study discusses the } \\
\text { factors that influence the exchange rate of the rupiah against dollar both in the } \\
\text { short and long term. The variables that are suspected to influence changes in }\end{array}$ \\
\hline $\begin{array}{l}\text { DOI Number: } \\
\text { 10.33059/jseb.v11i2.1919 } \\
\text { How to cite: } \\
\text { Wijaya, E. 2020. Analisis } \\
\text { Faktor-Faktor yang } \\
\text { Mempengaruhi Nilai Tukar } \\
\text { Rupiah Periode 1999Q1- } \\
\text { 2019Q2. Jurnal Samudra } \\
\text { Ekonomi dan Bisnis. 11(2): } \\
\text { 197-209. }\end{array}$ & $\begin{array}{l}\text { exchange rates are the inflation rate, the interest rate (SBI), world oil prices, } \\
\text { the value of exports, and the value of imports. This research was conducted } \\
\text { during } 1999 \text { quarter } 1 \text { to } 2019 \text { quarter } 2 \text {. The results showed that there was a } \\
\text { long-term and short-term relationship between inflation rates, interest rates, } \\
\text { world oil prices, exports and imports to the exchange rate. In the short term, the } \\
\text { interest rate and world oil prices have a significant effect on the exchange rate. } \\
\text { In the long run, the inflation rate, world oil prices and imports have a } \\
\text { significant effect on the exchange rate. } \\
\text { Keywords: Exchange Rate, Inflation, Interest Rate, World Oil Prices, Exports, } \\
\text { Imports. }\end{array}$ \\
\hline
\end{tabular}




\section{PENDAHULUAN}

Tinggi rendahnya perekonomian suatu negara tidak terlepas dari peran negara lain dalam hubungan internasional. Hubungan internasional dapat dilakukan dengan dua acara, yaitu pembelian dan penjualan barang dan jasa melalui ekspor dan impor, dan pembelian dan penjualan capital asset di pasar modal melalui penjualan instrument pasar modal, seperti saham, obligasi, dan lainlain. Di dalam kedua jenis hubungan internasional itu diperlukan alat transaksi yaitu uang dalam satuan internasional. Satuan internasional mata uang satu negara terhadap negara lainnya biasa disebut dengan kurs atau nilai tukar.

Samuelson \& Nordhaus (2010) memberi definisi atas nilai tukar mata uang sebagai harga satu mata uang dalam satuan mata uang negara lain. Karenanya bisa dinyatakan bahwa nilai tukar mata uang adalah harga dari mata uang suatu negara terhadap mata uang negara lain yang dipergunakan di dalam pelaksanaan perdagangan antara kedua negara tersebut dimana nilainya ditentukan melalui permintaan dan penawaran pada pasar valuta asing.

Ada dua jenis nilai tukar, yaitu nilai tukar nominal serta nilai tukar riil (Mankiw, 2018). Nilai tukar nominal merupakan harga suatu mata uang dibandingkan mata uang negara lainnya, contohnya Rp. 14.100 per \$1. Sementara nilai tukar riil adalah suatu tingkat dimana barang dan jasa suatu negara dapat ditukarkan dengan barang dan jasa negara lainnya, contohnya $0.75 \mathrm{~kg}$ beras di Indonesia per $1 \mathrm{~kg}$ beras di Malaysia. Nilai tukar riil dihitung dengan membandingkan hasil perkalian dari nilai tukar nominal dan tingkat harga luar negeri dengan tingkat harga dalam negeri. Dalam penelitian ini, nilai tukar yang dimaksud adalah antara rupiah terhadap dolar.
Banyak faktor yang menyebabkan kurs rupiah terhadap dollar mengalami fluktuasi baik apresiasi maupun depresiasi. Salah satu faktor yang mempengaruhi fluktuasi kurs adalah faktor makroekonomi. Penelitian ini mencoba untuk menganalisis faktor-faktor yang mempengaruhi fluktuasi kurs rupiah terhadap dollar dari sudut faktor makroekonomi. Adapun faktor makroekonomi yang digunakan meliputi inflasi, harga minyak dunia, ekspor, impor, dan tingkat bunga.

\section{Tingkat Inflasi}

Inflasi sebagai suatu proses kenaikan harga-harga umum dari barang-barang secara terus menerus (Nopirin, 2010). Inflasi secara sederhana bisa diartikan sebagai kecenderungan dari harga-harga untuk naik secara umum dan terus menerus (Boediono, 2013). Kenaikan harga-harga misalnya dikarenakan musim dan menjelang hari-hari besar, yang berarti kenaikan harga yang terjadi dalam suatu saat tertentu tidak memiliki pengaruh lanjutan bukan merupakan inflasi.

Inflasi pada intinya merupakan rata-rata kenaikan tingkat harga barang dan jasa. Tingginya tingkat inflasi dapat menyebabkan penurunan kesejahteraan masyarakat dengan kenaikan tingkat harga. Dampak inflasi juga dapat berpengaruh terhadap nilai tukar. Tinggnya inflasi menyebabkan harga barang dan jasa juga meningkat relatif terhadap harga barang dan jasa negara lain. Hal ini menyebabkan masyarakat akan membeli barang dan jasa dari negara lain yang akan berdampak nilai tukar rupiah akan mengalami depresiasi. Penelitian yang dilakukan Khan (2014), Dzakiyah et al. (2018), Anggraeni \& Suyahya (2016), serta Demak et al. (2018) menyatakan besaran inflasi berpengaruh negatif terhadap nilai tukar rupiah. Sedangkan penelitian Fauji (2016) menyatakan inflasi tidak berpengaruh terhadap nilai tukar rupiah. 
Berdasarkan uraian, maka hipotesis pertama yang dimunculkan dalam penelitian ini adalah:

H1: Inflasi memiliki pengaruh negatif terhadap nilai tukar dalam periode 19992018 baik pada jangka pendek maupun jangka panjang.

\section{Tingkat Bunga}

Mishkin (2014) mengemukakan tingkat bunga adalah biaya pinjaman atau harga yang dibayarkan untuk dana pinjaman tersebut (biasanya dinyatakan sebagai persentase per tahun). Tingkat bunga adalah ukuran investasi yang dapat diperoleh investor dan juga ukuran biaya modal yang harus dikeluarkan oleh perusahaan untuk menggunakan dana dari investor. Secara umum, tingkat bunga dibagi menjadi dua jenis, yaitu tingkat bunga nominal serta tingkat bunga riil. Tingkat bunga nominal adalah tingkat bunga yang tidak memasukkan unsur atau dampak inflasi dan tingkat bunga ini langsung dipublikasikan oleh pihak perbankan. Tingkat bunga riil merupakan tingkat bunga yang sudah dikoreksi dengan inflasi, yang mencerminkan pendapatan oleh penabung yang sudah menghilangkan dampak perubahan harga. Tingkat bunga SBI merupakan benchmark bagi investor untuk membandingkan investor dalam bidang lainnya.

Tingkat bunga juga merupakan balas jasa akan suatu kegiatan investasi. Semakin tinggi tingkat bunga berarti semakin tinggi return yang didapatkan oleh investor untuk investasi di pasar uang. Hal ini berarti semakin tinggi tingkat bunga di dalam negeri relatif terhadap tingkat bunga di luar negeri menyebabkan semakin banyaknya investor asing yang akan melakukan investasi di dalam negeri. Hal ini menyebabkan permintaan mata uang domestik meningkat yang berakibat nilai tukar rupiah menurun (apresiasi), sehingga akan memiliki dampak negatif terhadap nilai tukar mata uang negara tersebut yang akan mengalami apresiasi.

Penelitian yang dilakukan oleh Khan (2014), Parianom (2014), Permatasari \& Rosyidi (2017), Fauji (2016), Pardede \& Setiawina (2018), Setyowati (2003), serta Anggraeni \& Suyahya (2016) menyatakan bahwa tingkat bunga berpengaruh terhadap nilai tukar rupiah. Sedangkan hasil penelitian yang dilakukan oleh Hazizah et al. (2017), menemukan hasil bahwa tingkat bunga tidak berpengaruh terhadap nilai tukar rupiah.

Berdasarkan pemikiran telah dinyatakan, maka hipotesis kedua yang dimunculkan dalam penelitian ini adalah:

H2: Tingkat bunga memiliki pengaruh positif terhadap nilai tukar dalam periode 19992018 baik pada jangka pendek maupun jangka panjang.

\section{Harga Minyak Dunia}

Indonesia merupakan salah satu negara pengimpor minyak dunia. Harga Minyak mentah dunia diukur dari harga spot pasar minyak dunia (Artha et al., 2014), dan pada umumnya yang digunakan menjadi standar adalah West Texas Intermediate atau Brent. Minyak mentah yang diperdagangkan di WTI adalah minyak mentah yang berkualitas tinggi. Minyak mentah tersebut berjenis Light, Weight dan memiliki kadar belerang yang rendah. Minyak jenis ini cocok dijadikan bahan bakar, ini menyebabkan harga minyak ini dijadikan patokan bagi perdagangan minyak di dunia.

Kondisi yang terjadi adalah bahwa peningkatan harga minyak dunia dapat mempengaruhi nilai tukar rupiah. Kenaikan harga minyak dunia, akan menyebabkan Indonesia membeli minyak tersebut dengan harga yang lebih tinggi. Hal ini menyebabkan pembayaran dalam bentuk dollar meningkat 
sehingga akan menyebabkan mata uang rupiah akan mengalami depresiasi. Penelitian yang dilakukan oleh Khan (2014), Parianom (2014), serta Pardede \& Setiawina (2018), menyatakan bahwa harga minyak dunia berpengaruh negatif terhadap nilai tukar rupiah.

Berdasarkan pemikiran telah dinyatakan, maka hipotesis ketiga yang dimunculkan dalam penelitian ini adalah:

H3: Harga minyak dunia memiliki pengaruh negatif terhadap nilai tukar dalam periode 1999-2018 baik pada jangka pendek maupun jangka panjang.

\section{Nilai Ekspor}

Ekspor adalah barang dan jasa yang diproduksi didalam negeri tetapi dijual ke luar negeri (Mankiw, 2018). Perkembangan ekspor dari suatu negara tidak hanya ditentukan oleh faktor-faktor keunggulan komparatif tetapi juga oleh faktor-faktor keunggulan kompetitif. Inti dari paradigma keunggulan kompetitif adalah keunggulan suatu negara didalam persaingan global selain ditentukan oleh keunggulan komparatif (teoriteori klasik dan $\mathrm{H}-\mathrm{O}$ ) yang dimilikinya dan juga karena adanya proteksi atau bantuan fasilitas dari pemerintah, juga sangat ditentukan oleh keunggulan kompetitifnya. Keunggulan kompetitif tidak hanya dimiliki oleh suatu negara, tetapi juga dimiliki oleh perusahaan-perusahaan di negara tersebut secara individu atau kelompok. Perbedaan lainnya dengan keunggulan komparatif adalah, bahwa keunggulan kompetitif sifatnya lebih dinamis dengan perubahan-perubahan, misalnya teknologi dan sumber daya manusia.

Pemerintah saat ini sangat concern terhadap ekspor Indonesia. Banyak kebijakankebijakan pemerintah yang mendorong ekspor Indonesia ke negara lain. Kebijakan itu meliputi penyederhanaan prosedur ekspor dan efisiensi logistik. Simplifikasi prosedural ekspor dilakukan untuk memberikan efisiensi biaya dan waktu dengan pengurangan komoditas yang wajib menyertakan laporan surveyor (LS) dan Larangan Terbatas (Lartas) Ekspor lainnya. Hal ini didasarkan bahwa akhir-akhir ini Indonesia mengalami defisit neraca perdagangan yang mempunyai dampak terhadap nilai tukar rupiah.

Peningkatan ekspor akan mendorong meningkatnya penerimaan devisa pemerintah yang akan menyebabkan nilai tukar rupiah akan mengalami apresiasi. Peningkatan nilai ekspor akan memberikan efek positif terhadap nilai tukar. Penelitian yang dilakukan oleh Hazizah et al. (2017) menyatakan bahwa ekspor berpengaruh terhadap nilai tukar rupiah. Sedangkan penelitian yang dilakukan oleh Khan (2014), Permatasari \& Rosyidi (2017), Fauji (2016), serta Dzakiyah et al. (2018) menyatakan ekspor tidak memiliki pengaruh terhadap nilai tukar rupiah.

Berdasarkan pemikiran telah dinyatakan, maka hipotesis keempat dalam penelitian ini adalah:

H4: Nilai ekspor memiliki pengaruh positif terhadap nilai tukar dalam periode 19992018 baik pada jangka pendek maupun jangka panjang.

\section{Nilai Impor}

Tidak semua barang dan jasa yang dibutuhkan oleh penduduk Indonesia dapat dipenuhi dengan produksi dari dalam negeri. Berdsarkan hal itu, maka kegiatan impor dilakukan untuk memenuhi kebutuhan dalam negeri yang tidak dapat dipenuhi dari produksi sendiri.

Impor adalah barang dan jasa yang diproduksi di luar negeri dan dijual di dalam negeri (Mankiw, 2018). Pengertian ini memiliki arti bahwa kegiatan impor berarti melibatkan dua negara. Dalam hal ini bisa 
diwakili oleh kepentingan dua perusahaan antar dua negara tersebut, yang berbeda dan pastinya juga peraturan serta bertindak sebagai supplier dan satunya bertindak sebagai negara penerima. Impor adalah membeli barang-barang dari luar negeri sesuai dengan ketentuan pemerintah yang dibayar dengan menggunakan valuta asing.

Kegiatan impor yang dilakukan oleh suatu negara dapat memiliki dampak yang negatif terhadap nilai tukar. Semakin banyak impor berarti semakin banyaknya kebutuhan negara tersebut membayar dengan mata uang asing sehingga akan berdampak depresiasi mata uang dalam negeri. Penelitian yang dilakukan oleh Anggraeni \& Suyahya (2016) serta Hazizah et al. (2017) menyatakan bahwa impor berpengaruh terhadap nilai tukar rupiah. Sementara itu, hasil penelitian yang dilakukan oleh Khan (2014), Permatasari \& Rosyidi (2017), serta Fauji (2016), mengidentifikasi bukti bahwa nilai impor tidak berpengaruh terhadap nilai tukar rupiah.

Berdasarkan pemikiran telah diuraikan, maka hipotesis kelima yang dimunculkan dalam penelitian ini adalah:

H5: Nilai impor memiliki pengaruh negatif terhadap nilai tukar dalam periode 19992018 baik pada jangka pendek maupun jangka panjang.

Kerangka penelitian yang memberikan gambaran tentang kelima hipotesis hubungan antara variabel independen dan variabel dependen ditunjukkan dalam Gambar 1.

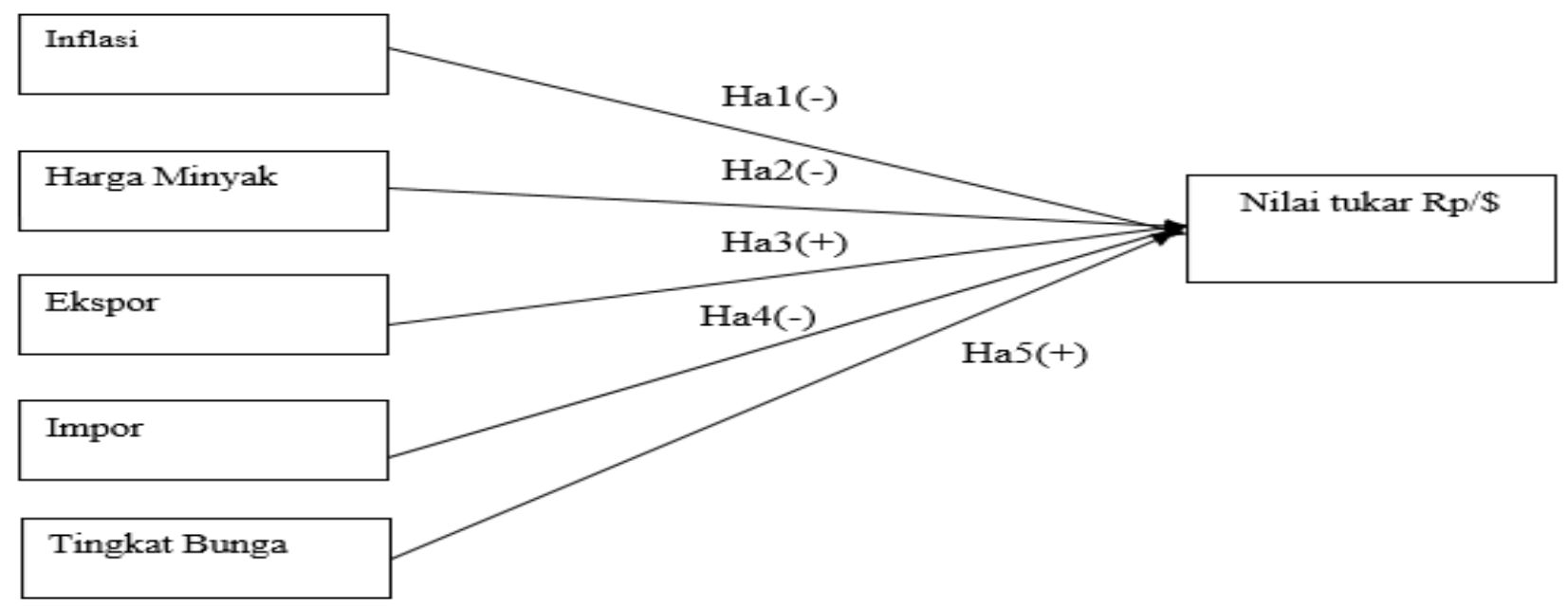

Gambar 1. Kerangka Penelitian

Sumber: Diolah penulis, 2019.

\section{METODE PENELITIAN}

\section{Objek Penelitian}

Penelitian ini menganalisis faktor-faktor yang mempengaruhi nilai tukar rupiah selama periode 1999Q1-2019Q2. Penelitian jenis kuantitatif dengan pendekatan deskriptif yang berlandaskan pada filsafat positivisme ini, digunakan untuk meneliti populasi atau sampel tertentu. Pengumpulan data menggunakan instrumen penelitian dan analisis data bersifat kuantitatif atau statistik, dengan tujuan untuk menguji hipotesis yang telah diterapkan (Sugiyono, 2013; Gujarati, 2013). Data yang digunakan berjangka kuartalan sepanjang periode penelitian.

Variabel makroekonomi yang dicakup dalam model penelitian ini meliputi inflasi, harga minyak dunia, ekspor, impor, dan tingkat bunga. Sumber data yang digunakan adalah website Bank Indonesia untuk data 
inflasi, nilai ekspor, nilai impor, dan tingkat bunga. Variabel nilai tukar, data didapatkan dari website mengenai pacific exchange rate, sementara variabel harga minyak dunia dari www.indexmundi.com.

\section{Model Ekonometrika}

Model dasar ekonometrika yang digunakan untuk menganalisis pengaruh makro ekonomi terhadap nilai tukar rupiah atas dollar $(\mathrm{Rp} / \$)$ adalah:

$$
\begin{aligned}
\mathrm{KURSt}= & \beta_{0}+\beta_{1} \mathrm{INFt}+\beta_{2} \mathrm{OILt}+\beta_{3} \mathrm{SBIt} \\
& +\beta_{4} \mathrm{LOGEXPt}+\beta_{5} \mathrm{LOGIMPt}+\varepsilon \mathrm{t}
\end{aligned}
$$

dimana KURS adalah rata-rata kurs rupiah atas dollar secara kuartalan; INF yaitu tingkat inflasi metode IHK secara kuartalan (\%); OIL adalah rata-rata harga minyak mentah Brent. Dubai, West Texas (equally weighted) secara kuartalan (USD); LOGEXP yaitu total ekspor Indonesia secara kuartalan (USD); LOGIMP adalah total impor Indonesia secara kuartalan (USD); SBI adalah rata-rata tingkat bunga SBI (\%); $\beta 0$ yaitu konstanta; $\varepsilon$ yaitu residual; dan, $\beta \mathrm{n}$ adalah koefisien regresi dari variabel.

Analisis penelitian meliputi pengaruh pada jangka panjang maupun jangka pendek. Analisis penelitian ini mencakup model jangka panjang serta model jangka pendek. Model jangka panjang diformulasikan:

$$
\begin{aligned}
\text { KURSt }= & \beta_{0}+\beta_{1} \mathrm{INFt}+\beta_{2} \mathrm{OILt}+\beta_{3} \mathrm{SBIt} \\
& +\beta_{4} \mathrm{LOGEXPt}+\beta_{5} \mathrm{LOGIMPt}+U \mathrm{t}
\end{aligned}
$$

dimana $\beta 0$ adalah konstanta; $U \mathrm{t}$ adalah residual; dan, $\beta \mathrm{n}$ adalah koefisien dari pengaruh jangka panjang.

Selanjutnya, model jangka pendek yang digunakan dalam penelitian ini diformulasikan sebagai berikut:

$$
\begin{aligned}
\mathrm{dKURSt}= & \alpha 1 \mathrm{dINFt}+\alpha 2 \mathrm{dOILt}+\alpha 3 \mathrm{dLOG} \\
& \text { EXPt }+\alpha 4 \mathrm{dLOGIMPt}+\alpha 5 \mathrm{dSBIt} \\
& -\square(\mathrm{KURSt}-1-\beta 0-\beta 1 \mathrm{INFt}-1- \\
& \beta 2 \text { OIL }-1-\beta 3 \mathrm{LOGEXPt}-1-\beta 4 \\
& \text { LOGIMPt }-1-\beta 5 \mathrm{SBIt}-1)+\mathrm{Vt}
\end{aligned}
$$

dimana $\alpha$ n adalah pengaruh jangka pendek; serta, 7 adalah koefisien standar adjustment $(0<7<1)$.

Penelitian ini menggunakan Error Correction Model (ECM) yang merupakan model yang digunakan untuk mengoreksi persamaan regresi di antara variabel-variabel yang secara individual tidak stasioner agar kembali ke nilai ekuilibriumnya di jangka panjang (Ajija et al., 2011). Metode ini menjelaskan hubungan jangka panjang serta jangka pendek dari variabel penelitian yang disebabkan karena adanya ketidakseimbangan hubungan pada model dan ketidaknormalan serta ketidakstasioneran data. Hipotesa penelitiannya adalah:

Ho: $\rho=0$, (terdapat ujit root, artinya data tidak stasioner)

Ha: $\rho \neq 0$, (tidak terdapat unit root, artinya data stasioner)

\section{HASIL ANALISIS}

\section{Pengujian Stasioneritas}

Hasil pengujian stasioner dapat dilihat pada Tabel 1. Berdasarkan hasil pengujian stasioner pada tingkat level, terdapat empat variabel yang tidak stasioner, yaitu: KURS, INFLASI, LOGEKSPOR, LOGIMPOR, dan OIL; sementara dua variabel yang stasioner pada tingkat level, yaitu SBI dan INFLASI. Oleh karena itu, pengujian akar-akar unit perlu dilanjutkan pada tingkat first difference (Ardana, 2016). Hasil pengujian akar pada first difference dapat dilihat pada Tabel 2.

Hasil pengujian stasioner pada derajat 1 dalam Tabel 2 menunjukkan semua variabel penelitian (yaitu: KURS, SBI, INFLASI, LOGEKSPOR, LOGIMPOR, dan OIL hanya telah stasioner pada tingkat derajat 1, sehingga dapat dilanjutkan tahapan pengujian efek jangka panjang (kointegrasi). 
Tabel 1. Hasil Pengujian Stasioner pada Tingkat Level

\begin{tabular}{|c|c|c|c|}
\hline No. & Variabel & Unit Root Test & Kesimpulan \\
\hline 1 & KURS & $0,8104 * * *$ & Tidak \\
\hline 2 & SBI & $0,0000^{*}$ & Stasioner \\
\hline 3 & INFLASI & $0,0000^{*}$ & Stasioner \\
\hline 4 & LOGEKSPOR & $0,3798 * * *$ & Tidak \\
\hline 5 & LOGIMPOR & $0,5282 * * *$ & Tidak \\
\hline 6 & OIL & $0,3374 * * *$ & Tidak \\
\hline
\end{tabular}

Ket: * 1\%;** 5\%;*** $10 \%$

Sumber: Data primer diolah, 2019.

Tabel 2. Hasil Pengujian Stasioner pada Derajat 1

\begin{tabular}{clcc}
\hline No. & \multicolumn{1}{c}{ Variabel } & Unit Root Test & Kesimpulan \\
\hline 1 & KURS & $0,0001^{*}$ & Stasioner \\
2 & SBI & $0,0000^{*}$ & Stasioner \\
3 & INFLASI & $0,0000^{*}$ & Stasioner \\
4 & LOGEKSPOR & $0,0000^{*}$ & Stasioner \\
5 & LOGIMPOR & $0,0000^{*}$ & Stasioner \\
6 & OIL & $0,0000^{*}$ & Stasioner \\
\hline
\end{tabular}

Ket: *1\%;** 5\%;*** $10 \%$

Sumber: Data primer diolah, 2019.

\section{Analisa Jangka Panjang}

Tahap selanjutnya yang dilakukan setelah uji akar unit dan uji derajat integrasi adalah uji kointegrasi. Uji kointegrasi bertujuan untuk mendapatkan hubungan jangka panjang yang stabil antara variabel-variabel yang terintegrasi pada derajat yang sama. Dari hasil uji stasioneritas sebelumnya diketahui bahwa seluruh variabel dalam penelitian ini terintegrasi pada derajat yang sama yaitu pada derajat satu (I(1)), sehingga dapat dilakukan uji kointegrasi.

Dalam penelitian ini uji kointegrasi yang digunakan adalah uji kointegrasi EngleGranger serta uji kointegrasi Johansen Cointegration Test. Pada keadaan dimana terdapat kointegrasi, maka persamaan regresi dapat diinterpretasikan sebagai long run multiplier yang mengukur pengaruh jangka panjang (long run effect) secara permanen (Muhammad, 2014).

Pada pengujian kointegrasi EngleGranger (Engle \& Granger, 1987), langkah awal yang dilakukan dalam uji kointegrasi adalah meregresi persamaan OLS, yaitu meregresi persamaan untuk memperoleh nilai residual (u). Kriteria pengujiannya adalah jika nilai prob < tingkat signifikansi $\alpha$ maka dinyatakan terdapat kointegrasi pada persamaan regresi. Hasil uji Engle-Granger dapat dilihat pada Tabel 3.

Pada Tabel 3 terdapat hasil dimana nilai prob sebesar $0.0022<\alpha=0.05$. Hasil bearti bahwa Ho ditolak, atau dapat dinyatakan bahwa variabel-variabel yang digunakan dalam model penelitian ini cenderung menuju pada keseimbangan jangka panjang. 
Tabel 3. Hasil Uji Akar Unit terhadap Residual Persamaan Regresi Jangka Panjang

Null Hypothesis: RESID01 has a unit root

Exogenous: Constant

Lag Length: 0 (Automatic - based on SIC, maxlag=11)

t-Statistic Prob.*

\begin{tabular}{lcccc}
\hline \hline Augmented Dickey-Fuller test statistic & -4.018560 & 0.0022 \\
\hline Test critical & & & \\
values: & $1 \%$ level & -3.513344 & & \\
& $5 \%$ level & -2.897678 & \\
& $10 \%$ level & -2.586103 & \\
& & & \\
\hline \hline
\end{tabular}

* MacKinnon (1996) one-sided p-values.

Sumber: Data primer diolah, 2019.

Hasil estimasi persamaan model regresi pada jangka panjang adalah:

\begin{tabular}{c}
\hline KURS $=-24698.63+145.24$ INFLASI $-2.127 S B I$ \\
$(0.0385) \quad(0.9437)$ \\
$+76.380 I L-2700.082 L O G($ EKSPOR $)$ \\
$(0.0000)$ \\
$+6682.35 L O G($ IMPOR $)$ \\
$(0.0000)$
\end{tabular}

Adj $\mathrm{R}^{2} \quad=0,7956$

Prob $($ F Statistic $)=0,0000$

Uji kointegrasi ini digunakan untuk mengetahui hubungan jangka panjang antara nilai tukar rupiah terhadap dollar (KURS) dengan tingkat inflasi (INFLASI), tingkat bunga (SBI), harga minyak dunia (OIL), nilai ekspor barang (EKSPOR), dan nilai impor barang (IMPOR). Berdasarkan hasil estimasi jangka panjang, terdapat tiga variabel yang signifikan pada $\alpha$ sebesar 0,05 yaitu tingkat inflasi (INFLASI), harga minyak dunia (OIL), dan nilai impor barang (IMPOR).

Pada jangka panjang, terdapat pengaruh positif dari INFLASI terhadap KURS. Nilai koefisien sebesar 145,24 pada nilai positif menyatakan bahwa setiap terjadi kenaikan atas nilai inflasi sebesar 1 persen maka rata- rata nilai tukar rupiah terhadap dollar akan menjadi meningkat (atau, terdepresiasi) sebesar Rp. 145,24/\$.

Variabel berikutnya yang berpengaruh terhadap nilai KURS adalah harga minyak dunia (OIL). Nilai koefien sebesar -76,389, yang berarti jika harga minyak dunia naik sebesar \$1 maka rata-rata nilai tukar rupiah terhadap dollar akan mengalami penurunan (apresiasi) sebesar Rp. 76,389/\$. Terakhir, variabel IMPOR mempengaruhi KURS dengan nilai koefisien sebesar 6.682,35; yang berarti jika nilai impor barang meningkat sebesar \$1 juta maka rata-rata nilai tukar rupiah akan meningkat (depresiasi) sebesar Rp.6.682,35/\$.

\section{Analisa Jangka Pendek}

Setelah melakukan uji asumsi klasik yang meliputi pengujian normalitas, multikolinearitas, heteroskedastisitas, dan otokorelasi, dan dinyatakan bahwa model penelitian ini tidak melanggar semua asumsi tersebut maka diperoleh hasil uji persamaan regresi untuk analisa jangka pendek. Hasil regresi menunjukkan bahwa nilai koefisien ECT pada model tersebut signifikan dengan nilai p-value sebesar 0.0070 dan bertanda koefisien yang 
negatif sebesar -0.150107 . Persamaan regresi untuk analisa jangka pendek dalam penelitian ini adalah:

\section{$d($ KURS $)=78.117+36.025 d($ INFLASI $)$}

(0.1288)

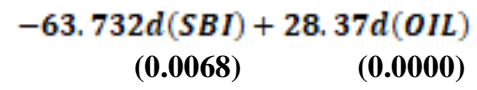

(0.0000)

+993.163dLog(EKSPOR)

(0.2731)

$+798.25 d \log ($ IMPOR $)-0.150 E C T(-1)$ (0.2339)

(0.0070)

$\begin{array}{ll}\operatorname{Adj} \mathrm{R}^{2} & =0.363 \\ \operatorname{Prob}(\mathrm{F} \text { stat }) & =0.000\end{array}$

Hasil regresi menunjukkan bahwa nilai koefisien ECT pada model tersebut signifikan dengan nilai $p$-value sebesar 0,0070 dan bertanda koefisien negatif sebesar -0,150107. Hasil estimasi ECM pada model tersebut memperlihatkan bahwa dalam jangka pendek terdapat dua variabel yang mempengaruhi nilai KURS, yaitu SBI dan OIL.

Nilai koefisien dari SBI sebesar 63,723 berarti jika tingkat bunga SBI mengalami meningkat sebesar $1 \%$, maka rata-rata nilai tukar akan menurun (apresiasi) sebesar Rp. 63,732/\$. Nilai koefisien dari OIL sebesar 28,37 berarti bahwa jika harga minyak dunia mengalami kenaikan sebesar $\$ 1$, maka ratarata nilai tukar rupiah terhadap dollar akan meningkat (depresiasi) sebesar Rp. 28,37.

Berdasarkan persamaan jangka pendek tersebut dengan menggunakan metode ECM maka menghasilkan koefisien ECT. Koefisien ini mengukur respon regressan setiap periode yang menyimpang dari titik keseimbangan. Menurut Widarjono (2018), koefisien koreksi ketidakseimbangan ECT dalam bentuk nilai absolut menjelaskan seberapa cepat waktu yang diperlukan untuk mendapatkan nilai keseimbangan. Nilai koefisien ECT sebesar -0,15 mempunyai makna bahwa perbedaan antara KURS dengan nilai keseimbangannya pada jangka panjang adalah sebesar -0,15. Error correction term menunjukkan seberapa cepat nilai ekuilibrium tercapai kembali ke keseimbangan jangka panjang.

\section{Pembahasan}

Penelitian ini bertujuan menganalisis pengaruh tingkat inflasi, tingkat bunga SBI, harga minyak mentah dunia, nilai ekspor, dan nilai impor terhadap nilai tukar $\mathrm{Rp} / \$$. Hasil penelitian ini menunjukkan bahwa variabelvariabel independen itu memiliki hubungan jangka panjang maupun jangka pendek terhadap nilai tukar Rp/\$. Hal ini dapat dilihat hasil Engle-Granger test dan Johanssen Cointegration test yang menguji hubungan jangka panjang, kesemuanya menunjukkan bahwa tingkat inflasi, tingkat bunga SBI, harga minyak mentah dunia, nilai ekspor, dan nilai impor memiliki hubungan jangka panjang atau terkointegrasi terhadap nilai tukar $\mathrm{Rp} / \$$.

Selain itu, pada hasil pengujian Error Correction Model (ECM) yang menguji hubungan jangka pendek juga menyatakan hasil yang signifikan yang ditunjukkan dari signifikansi Error Correction Term (ECT) pada persamaan tersebut. Karenanya dapat dinyatakan bahwa nilai tukar $\mathrm{Rp} / \$$ memiliki hubungan jangka panjang maupun jangka pendek dengan tingkat inflasi, tingkat bunga SBI, harga minyak mentah dunia, nilai ekspor, dan nilai impor.

\section{Analisis Hubungan Jangka Panjang}

Pada jangka panjang, hasil penelitian ini membuktikan bahwa tingkat inflasi, harga minyak dunia, dan nilai impor barang secara signifikan berpengaruh terhadap nilai tukar $\mathrm{Rp} / \$$. Nilai koefisien determinasi pada persamaan jangka panjang diperoleh bahwa variabilitas nilai kurs dapat dijelaskan oleh tingkat inflasi, tingkat bunga SBI, harga minyak dunia, nilai ekspor barang, dan nilai 
impor barang, sebesar 79,56\%. Sementara itu, sisanya sebesar 20,46\% menyatakan bahwa kurs juga dipengaruhi oleh faktor-faktor lain yang tak terdapat dalam model penelitian ini.

Tingkat inflasi menggambarkan kondisi kenaikan rata-rata harga barang dan jasa dalam periode waktu tertentu. Kenaikan harga ini memiliki dampak luas bagi masyarakat, yaitu daya beli masyarakat akan menurun bila harga barang-barang naik dan pendapatan masyarakat tetap. Apabila keadaan tersebut berlangsung dalam waktu lama maka akan berakibat banyaknya masyarakat yang akan masuk ke dalam kategori penduduk miskin.

Berdasarkan hasil penelitian, pada jangka panjang tingkat inflasi berpengaruh positif terhadap nilai tukar $\mathrm{Rp} / \$$. Hal ini berarti jika tingkat inflasi meningkat, maka rata-rata nilai tukar mengalami depresiasi. Kenaikan tingkat harga barang di dalam negeri secara relatif dibandingkan harga barang diluar negeri menyebabkan masyarakat lebih tertarik untuk membeli barang produk luar negeri. Sebagai konsekuensi, permintaan produk luar negeri meningkat yang berakibat pada permintaan mata uang asing khususnya dollar akan meningkat, dan pada akhirnya mata uang rupiah mengalami depresiasi.

Pengaruh tingkat inflasi terhadap kurs mata uang asing dapat dijelaskan dengan teori purchasing power parity (PPP Theory) atau teori paritas daya beli. Teori ini diperkenalkan oleh Gustav Cassel setelah Perang Dunia I. Berdasarkan teori PPP relatif dapat diketahui bahwa kurs mata uang akan berubah untuk mempertahankan level daya belinya. Dengan demikian dapat dikatakan kurs mencerminkan perbandingan antara nilai mata uang satu negara dengan negara lainnya yang ditentukan oleh daya beli dari masing-masing negara. Jika tingkat inflasi domestik lebih tinggi dari tingkat inflasi negara asing, maka nilai mata uang domestik mengalami kondisi depresiasi, sedangkan mata uang asing terapresiasi. Hal ini serupa dengan penelitian yang dilakukan oleh beberapa ahli, seperti Khan (2014), Dzakiyah et al. (2018), Anggraeni \& Suyahya (2016), serta Demak et al. (2018).

Nilai impor barang menunjukkan level belanja penduduk domestik terhadap barang produksi luar negeri akan mempengaruhi nilai tukar Rp/\$ pada jangka panjang. Hasol penelitian membuktikan angka koefisien dari nilai impor barang bertanda positif yang berarti bahwa pada periode jangka panjang kenaikan nilai impor barang dan jasa menyebabkan nilai kurs akan mengalami kenaikan (depresiasi). Hal ini disebabkan oleh permintaan akan mata uang asing khususnya dollar, akan meningkat untuk memenuhi kebutuhan pembelian barang dari luar negeri dan kondisi ini menyebabkan nilai tukar $\mathrm{Rp} / \$$ mengalami depresiasi. Hasil ini sama dengan hasil penelitian yang diperoleh Anggraeni \& Suyahya (2016) serta Hazizah et al. (2017).

Variabel terakhir yang mempengaruhi nlai tukar Rp/\$ dalam analisis jangka panjang adalah harga minyak dunia. Pergerakan harga minyak dunia dapat menyebabkan nilai kurs akan mengalami perubahan. Nilai koefisien harga minyak dunia diperoleh bertanda positif, yang berarti jika harga minyak dunia meningkat maka nilai kurs akan mengalami kenaikan (depresiasi). Hasil penelitian ini sejalan dengan penelitian yang dilakukan oleh Hazizah et al. (2017). Hal ini dapat terjadi karena Indonesia merupakan tipe negara pengimpor minyak dunia yang mana dari tahun ke tahun tingkat penggunaan atas bahan bakar minyak semakin meningkat, sehingga permintaan akan mata uang dollar bertambah tinggi dan akhirnya nilai tukar $\mathrm{Rp} / \$$ akan mengalami depresiasi.

\section{Analisis Hubungan Jangka Pendek}

Pada jangka pendek, hasil penelitian menemukan bahwa terdapat dua variabel yang 
mempengaruhi nilai tukar $\mathrm{Rp} / \$$, yaitu harga minyak dunia dan tingkat bunga SBI. Pengaruh jangka pendek secara signifikan dari harga minyak dunia terhadap nilai tukar $\mathrm{Rp} / \$$ juga sejalan dengan hasil analisis pada periode jangka panjang. Pembahasan terkait pengaruh haarga minyak duniaa terhadap kurs telah diuraikan pada hasil analisis jangka panjang sebelumnya.

Tingkat bunga SBI merupakan alternatif return investor selain investasi di pasar modal. Hasil analisis periode jangka pendek menyatakan bahwa perubahan yang terjadi pada tingkat bunga SBI akan menyebabkan perubahan pada nilai tukar $\mathrm{Rp} / \$$ dengan nilai koefisien sebesar -63,732. Berdasarkan hasil ini memberi makna bahwa jika tingkat bunga SBI meningkat maka rata-rata nilai kurs akan mengalami apresiasi. Tingginya tingkat bunga SBI mencerminkan tingginya tingkat bunga perbankan di Indonesia.

Kondisi tersebut mengakibatkan return investasi pada asset pasar uang dinilai relatif lebih menarik di Indonesia dibandingkan dengan negara-negara lain. Konsekuensinya menyebabkan banyak dari para investor asing yang memutuskan akan menempatkan dananya di Indonesia, sehingga suplai mata uang dollar akan meningkat yang berakibat nilai tukar Rp/\$ akan mengalami apresiasi. Hasil yang diperoleh penelitian ini serupa dengan penelitian yang dilakukan oleh Khan (2014), Parianom (2014), Permatasari \& Rosyidi (2017), Fauji (2016), Pardede \& Setiawina (2018), serta Anggraeni \& Suyahya (2016).

\section{SIMPULAN}

Berdasarkan hasil penelitian yang telah dipaparkan pada bagian sebelumnya, maka dinyatakan beberapa kesimpulan. Pertama, hasil penelitian ini membuktikan terdapat hubungan jangka panjang maupun jangka pendek dari tingkat inflasi, tingkat bunga SBI, harga minyak dunia, ekspor, dan impor terhadap nilai tukar rupiah/\$. Kedua, pada analisis jangka pendek, tingkat inflasi terbukti tidak mempengaruhi nilai tukar $\mathrm{Rp} / \$$, tetapi pada analisis jangka panjang dibuktikan bahwa tingkat inflasi berpengaruh positif atas nilai tukar $\mathrm{Rp} / \$$ atau bahwa kenaikan inflasi akan menyebabkan nilai tukar $\mathrm{Rp} / \$$ akan mengalami depresiasi.

Kesimpulan ketiga bahwa tingkat bunga SBI terbukti berpengaruh positif signifikan pada jangka pendek, sedangkan pada jangka panjang terbukti tidak berpengaruh terhadap nilai kurs; yang berarti bahwa setiap kenaikan tingkat bunga SBI berakibat nilai tukar Rp/\$ akan mengalami apresiasi. Keempat, harga minyak dunia dinyatakan berpengaruh secara negatif signifikan terhadap nilai tukar $\mathrm{Rp} / \$$ baik pada jangka pendek maupun pada jangka panjang; atau berarti bahwa setiap kenaikan harga minyak dunia akan berakibat nilai tukar $\mathrm{Rp} / \$$ mengalami apresiasi.

Kelima, nilai ekspor barang diperoleh terbukti tidak berpengaruh signifikan terhadap nilai tukar $\mathrm{Rp} / \$$ baik pada analisis jangka pendek maupun analisis jangka panjang. Terakhir, disimpulkan bahwa nilai impor barang hanya terbukti berpengaruh positif signifikan pada jangka panjang, sedangkan pada analisis jangka pendek terbukti tidak berpengaruh signifikan. Hal ini berarti bahwa pada jangka panjang, setiap kenaikan nilai impor barang akan menyebabkan nilai tukar $\mathrm{Rp} / \$$ mengalami depresiasi.

Berdasarkan kesimpulan tersebut, maka direkomendasikan beberapa hal. Pertama, direkomendasikan bagi pengusaha nasional untuk terus memasarkan produknya ke luar negeri sehingga cakupan wilayah perdagangan menjadi semakin luas dan tidak hanya mengandalkan perdagangan di dalam negeri. Selain itu, penggunaan bahan baku impor sebisa mungkin ditekan dan mengandalkan lebih pada bahan baku dalam negeri apabila tersedia. 
Bagi pemerintah direkomendasikan agar lebih memperhatikan beberapa indikator dari makroekonomi untuk menjaga kestabilan nilai tukar Rp/\$. Indikator makroekonomi tersebut adalah tingkat bunga, tingkat inflasi, dan impor barang. Selain itu, direkomendasikan bagi pemerintah supaya semakin mengurangi ketergantungan akan minyak mentah dunia dan berusaha untuk mengganti penggunaan bahan bakar berbasis fossil dengan alternatif bahan bakar lain, misalkan listrik dan BBG (bahan bakar gas). Sementara itu bagi penelitian selanjutnya, direkomendasikan agar perlu diteliti pengaruh dari variabel-variabel makroekonomi lainnya yang tidak dimasukkan dalam model penelitian ini terhadap nilai tukar rupiah terhadap dollar.

Namun demikian, penelitian ini disadari juga memiliki beberapa keterbatasan, Pertama adalah bahwa variabel ekspor dan impor hanya mencatat total nilai barang dan tidak mengakomodasi total nilai jasa; dan kedua adalah bahwa variabel tingkat bunga SBI, tidak sama pengambilan periode untuk tingkat bunga, karena keterbatasan informasi data tersebut. Para peneliti berikutnya diharapkan mengatasi keterbatasan-keterbatasan tersebut sehingga hasil penelitian diekspektasikan bisa menjawab permasalahan dalam topik ini secara lebih komprehensif.

\section{REFERENSI}

Ajija, S.R., Sari, D.W., Setianto, R.H., \& Primanti, M.R. 2011. Cara Cerdas Menguasai Eviews. Jakarta: Salemba Empat.

Anggraeni, W. \& Suyahya, I. 2016. Pengaruh antara Tingkat Suku Bunga, Tingkat Inflasi, dan Jumlah Barang Impor dengan Nilai Tukar Rupiah terhadap Dollar Amerika. Journal of Applied Business and Economics. 3(2): 81-89.

Ardana, Y. 2016. Pengaruh Variabel Makroekonomi terhadap Indeks Saham Syariah di Indonesia: Model ECM.
Esensi: Jurnal Bisnis dan Manajemen. 6(1): 17-28.

Artha, D.R., Achsani, N.A. \& Sasongko, H. 2014. Analisis Fundamental, Teknikal dan Makroekonomi Harga Saham Sektor Pertanian. Jurnal Manajemen dan Kewirausahaan (JMK). 16(2): 175-184.

Boediono. 2013. Ekonomi Makro. Yogyakarta: BPFE UGM.

Demak, U.D.L.K., Kumaat, R.J. \& Mandeij, D. 2018. Pengaruh Suku Bunga Deposito, Jumlah Uang Beredar, dan Inflasi terhadap Nilai Tukar Rupiah terhadap Dollar. Jurnal Berkala Ilmiah Efisiensi. 18(2): 181-192.

Dzakiyah, Z., Puspitaningtyas, Z. \& Puspita, Y. 2018. Pengaruh Jumlah Nilai Ekspor dan Tingkat Inflasi terhadap Kurs Rupiah Tahun 2009-2016. Jurnal Perilaku dan Strategi Bisnis. 6(2): 103-110.

Engle, R.F. \& Granger, C.W.J. 1987. CoIntegration and Error Correction: Representation, Estimation, and Testing. Econometrica. 55(2): 251-276.

Fauji, D.A.S. 2016. Faktor-Faktor yang Mempengaruhi Nilai Tukar Rupiah Periode 2013 - Triwulan I 2015. 2016. Jurnal Nusantara Aplikasi Manajemen Bisnis. 1(2): 64-77.

Gujarati, D.N. 2013. Basic Econometrics. : New York: McGraw Hill.

Hazizah, N., Viphindrartin, S. \& Zainuri, Z. 2017. Pengaruh JUB, Suku Bunga, Inflasi, Ekspor dan Impor terhadap Nilai Tukar Rupiah atas Dollar Amerika Serikat. e-Journal Ekonomi Bisnis dan Akuntansi. 4(1): 97-103.

Khan, R.S.A. 2014. Analysis if the Factors affecting Exchange Rate Variability in Pakistan. IOSR Journal of Business and Management. 16(6): 115-121.

Mankiw, N.G. 2018. Principles of Economics. $8^{\text {th }}$ Edition. Boston, MA: Cengage.

Miskhin, F.S. 2014. Ekonomi Uang, Perbankan dan Pasar Keuangan. Edisi 9, Jilid 2. Jakarta: Salemba Empat. 
Muhammad, M. 2014. Kointegrasi dan Estimasi ECM pada Data Time Series. Jurnal Konvergensi. 4(1): 41-51.

Nopirin. 2010. Ekonomi Moneter. Edisi 1, Cetakan 12. Yogyakarta: BPFE.

Pardede, A.S.M. \& Setiawina, N.D. 2018. Pengaruh Indeks Harga Saham Gabungan, Suku Bunga dan Harga Minyak Dunia terhadap Nilai Tukar Rupiah Tahun 2012 - 2016. E-Jurnal Ekonomi Pembangunan Universitas Udayana. 7(8): 1708-1736.

Parianom, R. 2014. Perilaku Nilai Tukar Rupiah: Pendekatan Behavior Equilibrium Exchange Rate (BEER). Jurnal Bijak. 11(2): 1-10.

Permatasari, Y.T. \& Rosyidi, S. 2017. Pengaruh Variabel Makro terhadap Nilai Tukar Rupiah atas Dolar AS
Periode 2012-2015. Jurnal Ekonomi Syariah Teori dan Terapan. 4(7): 587598.

Samuelson, P.A. \& Nordhaus, W.D. 2010. Economics. $19^{\text {th }}$ Edition. New York: McGraw-Hill.

Setyowati, E. 2003. Faktor-Faktor yang Mempengaruhi Nilai Tukar Rupiah terhadap Dolar Amerika dengan Model Koreksi Kesalahan Engle-Granger (Pendekatan Moneter). Jurnal Ekonomi Pembangunan. 4(2): 162-186.

Sugiyono. 2013. Metode Penelitian Bisnis. Bandung: CV. Alfabeta.

Widarjono, A. 2018. Ekonometrika Pengantar dan Aplikasinya disertai Panduan EViews. Edisi 5. Yogyakarta: UPP STIM YKPM. 